\section{Pre 05}

MALTIENANT MELANOMA AND PREGNANCY

E.W.Breitbart and Th. Nasenam

Confusion exists concerring the influence of pregnancy on survival in patients with malignant melanoma. The reason is, that the effects of pregnancy or homonal manipulation on the pathogenesis and metastatic spread of malignant melanoma is unclear. On one side the presence of steroid receptars (SR) (E.T. Creagan et al., Cancer Treatment Reports $64,199,1980$ ), estradiol receptors ( $(R)$ and progesterone receptors (PoR) (M. Fernö et al., Anticancer Research 4, 179, 1984) in melanoma has been reported. On the other side there is no carrelation between the detected receptorproteins and the hormonal. influence on the melanoma growth phase. In literatume there is conformity that there is no change in the 5 year survival rate in comparison to non-pregnant females, if the melanama is diagnosed during pregnancy. An improvenent of the 5 year survival rate is described for females with multiple pregnancies before developing a melanoma. A decrease of the 5 year survival rate is found for pregnant females in stage II, and again there occurs no change in prognosis in case of pregnancy after melanoma excision. All this makes the medical advice for pregnant females difficult. According to the most important prognostic factor, the tumorthickness, it is possible to justify the following procedure:

\begin{tabular}{l|l|l|l} 
classification & treatment & interruption & contraception \\
\hline $\begin{array}{l}\text { stage I } \\
\text { tumorthickness } \\
<1,5 \mathrm{~mm}\end{array}$ & $\begin{array}{l}\text { excision } \\
(3 \mathrm{~cm})\end{array}$ & no interruption & $\begin{array}{l}\text { for } 3 \text { years } \\
\text { without hor- } \\
\text { mones }\end{array}$ \\
$\begin{array}{l}\text { stage I } \\
\text { tumorthickness }\end{array}$ & $\begin{array}{l}\text { excision incl. } \\
\text { lymphnodedis- } \\
\$ 1,5 \mathrm{~mm}\end{array}$ & $\begin{array}{l}\text { interruption } \\
\text { (individual } \\
\text { decision) }\end{array}$ & $\begin{array}{l}\text { for } 5 \text { years } \\
\text { without hor- } \\
\text { mones }\end{array}$ \\
stage II-III & operation & interruption & sterilisation \\
\hline
\end{tabular}

Universitäts-Hautklinik Hamburg-Eppendorf, Martinistraße 52, D-2000 Hanburg 20
Pre 07

ASPECTS OF CONTRACEPTION IN FEVALE CANCER PATIENTS

W. Saucrwein, R. Callies, M. Nohlen, P.F.Tauber Pregnancies of women with cancer are usually unwanted and may represent a medical, eugenic or psychological problem. Frequently, contraceptive counseling has been insufficient. Within the last year, 5 unwanted pregnancies were observed in women following completed treatment of either Hodgkin's diseas or breast cancer. Among an annual 150 female outpatients with various malignant tumors and at risk of pregnancy, the above 5 women represent a clinical in cidence of $3.3 \%$ of unwanted pregnancies. One case was due to oc failure and 4 cases occurred for incompetent counseling. Reasons given to the patients for abstaining from contraception were assumed negative influences of hormones upon the malignant condition. Four pregnancies went to term and healthy babies were delivered. One was terminated for psychosocial grounds. Pregnancies of cancer patients after treatment are relatively safe with regard to malformation, although they should not occur unwantedly for psychological reasons. For these patients, safe contraception is desired, but in contrast is absolutely necessary during cancer treatment. Among the contraceptive methods available, the intrauterine device seems to meet all needs. Barrier contraception with adequate counseling for its use may also be recommended. Oral contracentives hovever, might not be suitable 1. in suspected hormone dependent tumors and 2. when occasional vomiting is expected. Sterilization may be advised in women over 35 years of age. Further studies into this clinical problem should be of value.

Strahlenklinik and Frauenklinik

Universitätsklinikum Essen D-4300 Essen 1

\section{Pre 08}

PREGNANCY FOILOWING RADIO-ONCOLOGICAI THERAPY: ASPECTS OF GENETIC COUNSEIING W. Sauerwein and E. Passarge Successful radio-oncological therapy allows an increasing number of patients to lead a normal life and become parents. Anxiety results from fear of sosible mutagenic or teratogenic effects of the previous therapy. On the basis of theoretically possible risks patients are not infrequently advised by physicians to advoid or to terminate pregnancy following cancer therapy. Between 1978 and 1985 we re-assessed 30 tumor patients who seeked genetic counseling. They had received radiotherapy (17), chemotherapy (2) or a combination of both (11). 19 couples came prior to pregnancy, 11 during pregnancy, of the latter, 5 explicitly came to confirm that termination of pregnancy was necessery. Two women had previous1.y terminated a pregnancy for fear of a mutagenic rick to their offspring. In the prior-toconception situations we counseled that cancer therapy would not constitute a recognizable individual mutagenic risk. Thus, a pregnancy could weIl be considered. We recommended an interval of about 6-12 months following therapy. Once a pregnancy had occurred, we recommended that it could be continued. In no instance was a child born with congenital developmental defects. In spite of the theoretically expected mutagenic risk of radio-oncological therapy, empirical observations do not indicate that such risk exists. For counseling purooses it appears to be important to distinguish a theoretically possible risk, the demand for formal exclusion of such a risk, and the actual lack of evidence for an increased risk.

Strahlenklinik and Institut für Humangenetik Universitätsklinikum D - 4300 Essen 1 